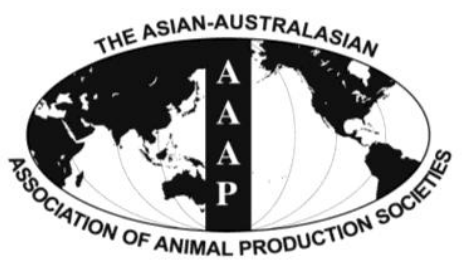

Asian Australas. J. Anim. Sci.

Vol. 26, No. 9 : 1339-1346 September 2013

http://dx.doi.org/10.5713/ajas.2013.13079

www.ajas.info

pISSN 1011-2367 elSSN 1976-5517

\title{
Efficacy of Tomato Powder as Antioxidant in Cooked Pork Patties
}

\author{
I. S. Kim, S. K. Jin, M. R. Yang, G. M. Chu, J. H. Park, R. H. I. Rashid, J. Y. Kim, and S. N. Kang* \\ Department of Animal Resources Technology, Gyeongnam National University of Science and Technology, \\ Gyeongnam, 660-758, Korea
}

\begin{abstract}
This study was carried out to determine the effects of tomato powder (TP) on cooked pork patties during storage at $10 \pm 1^{\circ} \mathrm{C}$ in the dark. The total phenolic and flavonoid contents of TP extract were $26.22 \mathrm{mg}$ gallic acid/100 $\mathrm{g}$ and $3.52 \mathrm{mg}$ quercetin/100 $\mathrm{g}$, respectively. The extract of TP showed a potential antioxidant activity in the DPPH radical-scavenging assay $\left(\mathrm{EC}_{50}=16.76 \mu \mathrm{g} / \mathrm{mL}\right)$. Pork patties were manufactured with $0.25 \%$ (T1), $0.5 \%$ (T2), $0.75 \%$ (T3) and $1.0 \%$ (T4) TP in a basic formula (C). The pH and volatile basic nitrogen $(\mathrm{VBN})$ values of T2, T3 and T4 patties were lower $(\mathrm{p}<0.05)$ than the $\mathrm{C}$ patties during storage. Increased concentration of TP in meat patties decreased $(\mathrm{p}<0.05)$ the 2-thiobarbituric acid reactive substances (TBARS) and total plate count $($ TPC) values at $\mathrm{d} 7$ of storage. Tomato treated-patties had lower $(\mathrm{p}<0.05)$ values for lightness $\left(L^{*}\right)$, but higher $(\mathrm{p}<0.05)$ values for redness $\left(a^{*}\right)$ and yellowness $\left(b^{*}\right)$ at $\mathrm{d} 3$ and 7 of storage compared with the $\mathrm{C}$. In the case of sensory evaluation, the scores of colour, flavour and overall acceptability of T3 and T4 patties were higher ( $\mathrm{p}<0.05)$ than those of the $\mathrm{C}$ patty after 3 or 7 days of storage. (Key Words: Tomato Powder, Natural Antioxidant, Pork Patties, Antioxidant Activity, Sensory Evaluation)
\end{abstract}

\section{INTRODUCTION}

The preference of consumers for naturally derived colourants is associated with their image of being healthy and of good quality. Beside this some synthetic colourants are considered responsible for allergenic and intolerance reactions (Østerlie and Lerfall, 2005). Recent studies have indicated a diet rich in tomato and tomato products possess potential health benefits (Tapiero et al., 2004). Tomato contains not only the nutritional antioxidants such as vitamin $\mathrm{A}, \mathrm{C}$, and $\mathrm{E}$, but also a great quantity of nonnutritional antioxidants, such as beta-carotene, carotenoids, flavonoids, flavones, and phenolics compounds, etc. (Havsteen, 1983; Hudson and Lewis, 1983; Vinson et al., 1998; Khachik et al., 2002). Lycopene, a major carotenoid present in tomatoes, is known to decrease risk of chronic diseases, such as cancer and cardiovascular diseases (Grieb et al., 2009; Zhang et al., 2009). In fact, most of the lycopene contents of tomato are associated with the water insoluble fraction and they can also be solubilized in heated oil (Hornero-Méndez and Mínguez-Mosquera, 2007). Moreover, it is observed that the bioavailability of lycopene

\footnotetext{
* Corresponding Author: Suk Nam Kang. Tel: +82-55-751-3512, Fax: +82-55-751-3689, E-mail: whitenightt@ hanmail.net Submitted Jan. 31, 2013; Accepted Apr. 22, 2013; Revised May 26, 2013
}

from tomatoes is substantially improved by heating tomatoes in oil (Stahl and Sies, 1992; Gartne et al., 1997; Sies and Stahl, 1998). For that reason, Herry et al. (1998) pointed out that the presence of oil is a factor in the isomerization reaction and the antioxidant in oil protects the trans- and cis-lycopene isomers against oxidation.

However, few studies have reported on the use of tomato products in meat and meat products (Candogan 2002; Yilmaz et al., 2002; Sánchez-Escalante et al., 2003; Østerlie and Lerfall, 2005; Deda et al., 2007). The present study addresses the utilization of different levels of tomato powder heated with oil as a natural ingredient in meat products. The objective was to evaluate the antioxidant properties of tomato powder (TP) and effects of TP on lipid oxidation, colour stability, microbial growth and sensory evaluation of processed pork patties during refrigerated storage.

\section{MATERIALS AND METHODS}

\section{Preparation of tomato powder and extract}

Fresh tomatoes were obtained from the Agricultural Products Wholesale Market (Jinju, South Korea). Tomatoes were washed, diced, and dried for $8 \mathrm{~h}$ at 50 in a hot-air drying oven (DMC-122SP, Daeil Engr. Co., Korea). The resulted tomato paste $(5 \mathrm{~kg})$ was mixed with olive oil (140 
$\mathrm{mL}$ ), dried at $80^{\circ} \mathrm{C}$ for $2 \mathrm{~h}$ and heated at $60^{\circ} \mathrm{C}$ for $72 \mathrm{~h}$ in a hot-air drying oven. The dry yield was $6.07 \%$ of the fresh tomatoes. The dried tomato was then pulverized using a blender (3030, Hsign Feng Enterprise Factory, Taiwan) and sieved through a stainless sieve (40 mesh). The resulted TP was then sealed and kept in $-40^{\circ} \mathrm{C}$. This final TP scored the following colour values using spectrocolorimeter (CR 400, Minolta Co., Japan): lightness ( $\left.L^{*}\right)$ 46.24, redness (a*) 8.26, yellowness $\left(b^{*}\right)$ 6.26. In order to evaluate antioxidant properties of TP, the TP was extracted using the method of Barba et al. (2006), repeated twice, with a solvent (hexane: acetone: ethanol $=50: 25: 25, \mathrm{v} / \mathrm{v} / \mathrm{v}$ ) by maceration at room temperature for $4 \mathrm{~h}$. The extracts were filtered (Whatman No. 1) and evaporate- dried (Heidolph, RW-0524G, Germany) below $45^{\circ} \mathrm{C}$.

\section{DPPH free radical scavenging activity}

Scavenging activity on DPPH free radicals by the TP extract was assessed according to the method reported by Gyamfi, Yonamine, and Aniya (1999) with slight modifications. Briefly, a $100 \mu \mathrm{L}$ solution of TP extract at different concentrations ( 5 to $100 \mu \mathrm{g} / \mathrm{mL}$ ) in ethanol was mixed with $100 \mu \mathrm{L}$ of $0.1 \mathrm{mM}$ DPPH in ethanol. The mixtures were shaken vigorously and allowed to stand at room temperature in the dark for $25 \mathrm{~min}$. Blank solutions were prepared with each test sample solution $(100 \mu \mathrm{L})$ and $100 \mu \mathrm{L}$ of ethanol while the negative control was $100 \mu \mathrm{L}$ of $0.1 \mathrm{mM}$ DPPH solution plus $100 \mu \mathrm{L}$ of ethanol. L-Ascorbic acid was used as the positive control. Thereafter, the absorbance of the assay mixture was measured at $518 \mathrm{~nm}$ against each blank in a spectrophotometer (Ultrospec 2100 pro; Amersham Pharmacia Biotech Co., Piscataway, NJ, USA). Lower absorbance of a reaction mixture indicates a higher radical scavenging activity. DPPH radical scavenging activity was calculated using the equation:

$\%$ scavenging activity

$=100-\left(\left(\mathrm{A}_{\mathrm{s}}-\mathrm{A}_{0}\right) /\right.$ Abs control $) \times 100$

Where $A_{0}$ is the absorbance of the blank, and $A_{s}$ is the absorbance of the tested sample. The $\mathrm{EC}_{50}$ value represented the concentration of the sample leading to $50 \%$ reduction in the initial DPPH concentration.

\section{Total phenolic content}

Total phenolic contents of the TP extract were determined spectrophotometrically according to the FolinCiocalteu colourimetric method (Singleton and Rossi, 1965). Because gallic acid is one of the polyphenol compounds, total phenolic content of TP extract was expressed as microgram gallic acid equivalents $/ 100 \mathrm{~g}$.

\section{Total flavonoid content}

Total flavonoid content of the TP extract was determined using the method of Meda et al. (2005) with minor modifications. In brief, $0.25 \mathrm{~mL}$ of sample $(50$ $\mu \mathrm{g} / \mathrm{mL}$ was added to a tube contained $1 \mathrm{~mL}$ of doubledistilled water. Then, $0.075 \mathrm{~mL}$ of $5 \% \mathrm{NaNO}_{2}, 0.075 \mathrm{~mL}$ of $10 \% \mathrm{AlCl}_{3}$ and $0.5 \mathrm{~mL}$ of $1 \mathrm{M} \mathrm{NaOH}$ were added at 0,5 and $6 \mathrm{~min}$, sequentially. Finally, the volume of solution was adjusted to $2.5 \mathrm{~mL}$ with double-distilled water. The absorbance of the solution was detected at a wavelength of $410 \mathrm{~nm}$ in a spectrophotometer (Ultrospec 2100 pro; Amersham Pharmacia Biotech Co., Piscataway, NJ, USA). Quercetin an ubiquitous flavonoid and found in many plant extracts, was used as a standard to quantify the total flavonoid contents. Results were expressed in microgram quercetin equivalents $(\mathrm{QE}) / \mathrm{gram}$.

\section{Meat patty manufacture}

Commercial fresh pork loin and back-fat were obtained from a local meat market, trimmed to separable fat. The lean meat and the pork back-fat were separately ground through a $10 \mathrm{~mm}$ plate and then through a $5 \mathrm{~mm}$ plate in a chopper (PM-98, MANCA, Spain). Ground meat and backfat were thoroughly mixed with salt, seasoning and ice in a mixer (Model 5K5SS, USA). Seasonings and additives were obtained from MSC Co., Ltd. (Seongnam, South Korea). Meat patties were prepared according to the following formula $(\%, w / w)$ : ground pork (80), ground fat (10), salt (1.2), pepper (0.3), and distilled water or TP (8.5). Four levels of TP were $0.25 \%$ (T1), $0.5 \%$ (T2), $0.75 \%$ (T3) and $1.0 \%$ (T4). All treatments, about $2.0 \mathrm{~kg}$ each, were replicated three times from separate meat sources at three different periods. Pork patties were made with a hamburger patty maker (CAPACITY HM-10, China) to be $2 \mathrm{~cm}$ thick and weight approximately $50 \mathrm{~g}$ and were cooked in a single grill (TG101-E, HOLLAND Co., Korea) at $170^{\circ} \mathrm{C}$ for $1 \mathrm{~h}$ (until reaching an internal temperature of $75^{\circ} \mathrm{C}$ ). The cooked patties were chilled for $2 \mathrm{~h}$ at $4 \pm 1^{\circ} \mathrm{C}$, aerobically packed, and stored at $10^{\circ} \pm 1^{\circ} \mathrm{C}$ in the dark until subsequent analysis.

\section{pH of pork patties}

$\mathrm{pH}$ measurements were determined by blending $10 \mathrm{~g}$ of pork patties with $90 \mathrm{~mL}$ distilled water for $30 \mathrm{~s}$ (T25B, IKA Sdn. Bhd., Malaysia). Readings were taken with $\mathrm{pH}$ meter (8603, Metrohm, Swiss).

\section{Lipid oxidation determination of pork patties}

The lipid oxidation was determined through 2thiobarbituric acid reactive substances (TBARS) in $\mathrm{mg}$ malondialdehyde (MDA)/kg of meat as described by Tarladgis et al. (1960). 


\section{Volatile basic nitrogen ( $\mathrm{VBN}$ ) values of pork patties}

A micro-diffusion method described by Pearson (1968) was modified for the determination of VBN. The homogenized sample of each patty $(10 \mathrm{~g})$ was mixed with $90 \mathrm{~mL}$ distilled water, blended for $10 \mathrm{~s}$ at low speed (Waring Blendor Model 34BL97) and filtered through Whatman No. 2 filter paper. One milliliter of filtrate was pipetted to a Conway dish contained $1 \mathrm{~mL}$ saturated $\mathrm{K}_{2} \mathrm{CO}_{3}$ solution and allowed for reaction at $37^{\circ} \mathrm{C}$ for $120 \mathrm{~min}$. Boric acid solution contained an indicator (methyl red and bromocresol green) was used to absorb volatile nitrogen. The solution was titrated with $0.01 \mathrm{~N} \mathrm{HCl}$ and $\mathrm{VBN}$ value was expressed as $\mathrm{mg}$ VBN/100 $\mathrm{g}$ of the sample.

\section{Colour measurement of pork patties}

Colour of pork patties was measured instrumentally in a spectrocolourimeter (CR 400, Minolta Co., Japan) ( $\lambda$ : $\left.400.700 \mathrm{~nm}, \Delta \lambda: 10 \mathrm{~nm}, \mathrm{D} 65,10^{\circ}\right)$ calibrated with a white plate and light trap that was supplied by the manufacturer. Colour of pork patties was expressed using the CIE $L^{*} a^{*} b^{*}$ colour system (CIE, 1976).

\section{Microbial analysis of pork patties}

Duplicated samples of patties $(25 \mathrm{~g})$ were taken aseptically from each treatment, transferred into sterile plastic pouches and homogenized in $225 \mathrm{~mL}$ of sterile $0.1 \%$ peptone water for $3 \mathrm{~min}$ at room temperature in a stomacher Lab-Blender 78860 (ST-Nom, Interscience, France). Appropriate dilutions of samples were prepared in sterile $\mathrm{NaCl}$ solution $(0.88 \%$, w/v), plated in duplicates onto plate count agar (PCA; Difco Laboratory, Detroit, MI, USA) and incubated at $35^{\circ} \mathrm{C}$ for $48 \mathrm{~h}$ under aerobic conditions so as to count the total bacteria. E. coli were incubated on E.coli/Coliform count plate petrifilm (3M Health care, USA) at $32^{\circ} \mathrm{C}$ for 2 days under the same aerobic conditions. Results were expressed as $\log _{10} \mathrm{CFU}$ (colony forming units)/g patties on days 1, 3 and 7 of storage.

\section{Sensory evaluation of pork patties}

Samples were assessed by a trained panel of 12 members. To acquaint panelists with product attributes and intensities, six training sessions, $1 \mathrm{~h}$ each, took place over a week period prior to sample testing. During this phase, samples from a variety of manufacturers corresponding to maximum and minimum intensities that might be found for each attribute (1: extremely undesirable, to 9: extremely desirable) were presented to panelists. To test the panel reproducibility, one additional sample was presented at each session. It was the replicate of the second sample of the set and was served at the end of the session. Slices $(3 \mathrm{~mm}$ thick) of randomly coded samples were obtained and served on plates to panelists. The colour, flavor and overall acceptability of the samples were evaluated using a 9-point descriptive scale where (1) refers to extremely undesirable and (9) refers to extremely desirable. Panelists were required to cleanse palate between samples with water and bread. Three samples from different packages at $\mathrm{d} 1,3$, and 7 of storage were successively evaluated in each session. The sample order was randomized within sessions at room temperature.

\section{Statistical analysis}

An analysis of variance was performed on all the variables measured according to the general linear model procedure of the SAS statistical package (SAS Institute, 1999). The total number of samples was 200 (20 burgers per batch $\times 5$ different batches $\times 2$ replicates each). The Duncan's multiple range test $(p<0.05)$ was applied to determine any differences between means of treatments.

\section{RESULTS AND DISCUSSION}

\section{Total phenolic and flavonoid contents of TP extract}

Phenols are very important plant constituents, because of their scavenging ability on free radicals that's believed to be an action of hydroxyl groups (Hemi et al., 2002). Analysis of total phenolic and flavonoid contents in the TP extracts was shown in Table 1. The total phenolic content and total flavonoid contents of the TP extracts were 26.22 $\mathrm{mg}$ gallic acid/ $100 \mathrm{~g}$ and $3.52 \mathrm{mg}$ quercetin/100 g, respectively. A similar observation was reported before (Toor and Savage, 2005), who found that the total phenolic contents (expressed as mg gallic acid equivalents/100 g) of skin, seeds and pulp of tomatoes ranged between 2.7 and $29.1 \mathrm{mg} / 100 \mathrm{~g}$, while the flavonoid contents of tomatoes obtained from skin, seeds and pulp were $8.7,2.8$ and $1.6 \mathrm{mg}$ lutein equivalents/100 g. Dietary intake of flavonoids-rich food has been connected with reduced risks of some cancers (lung, colorectal, and gastric) and also with low incidences of coronary heart diseases (Hertog et al., 1993; Hollman et al., 1996; Knekt et al., 1997; Garcia-Closas et al., 1999).

\section{Free radical scavenging activity of TP extract}

2,2-diphenyl-1-picrylhydrazyl radical (DPPH) is a stable free radical, and researchers have used this reaction

Table 1. Extraction yield, total phenolic and total flavonoid content of tomato powder extract

\begin{tabular}{lc}
\hline & Composition $^{1}$ \\
\hline Extraction yield $(\%)^{2}$ & $98.00 \pm 1.05$ \\
Total phenolic content & $26.22 \pm 3.20$ \\
$(\mathrm{mg}$ gallic acid/100 g) & \\
Total flavonoid content & $3.52 \pm 0.18$ \\
$(\mathrm{mg}$ quercetin/100 g) & \\
${ }^{1}$ Values are mean of triplicate determinations. \\
${ }^{2}$ Base on $100 \mathrm{~g}$ dry powder wt.
\end{tabular}


system to evaluate the efficiency of antioxidants (BrandWilliams et al., 1995; Bondet et al., 1997; Sánchez-Moreno et al., 1998). The addition of the TP extract to DPPH solution caused a rapid decrease in absorbance at $518 \mathrm{~nm}$ as an indication to its good scavenging capacity. As shown in Table 2, the TP extract possessed substantial dosedependent antioxidant activity and almost a complete scavenging of DPPH radical was observed at $25 \mu \mathrm{g} / \mathrm{mL}$ of the extract $\left(\mathrm{EC}_{50}=76.15 \mu \mathrm{g} / \mathrm{mL}\right)$, which was comparable to the activity of the control. i.e., L-ascorbic acid $\left(\mathrm{EC}_{50}=\right.$ $12.23 \mu \mathrm{g} / \mathrm{mL}$ ), which was used as a control antioxidant (Padayatty et al., 2003). Phytochemical analysis showed high total phenol contents in the TP extract suggesting, therefore, that the phenolic compounds present in the extract could be responsible for the observed DPPH radical scavenging activity, since they can readily donate hydrogen atoms. Hence, such TP extract could be applied as a natural antioxidant to limit the damage caused by free radicals in the human body. It is possible to conclude that the tested TP extract is a good source of antioxidants in terms of total phenolic and flavonoid contents and their associated free radical scavenging activity.

\section{pH of pork patties}

Figure 1A shows the results for $\mathrm{pH}$ values of cooked pork patties mixed with TP during storage at $10 \pm 1^{\circ} \mathrm{C}$. The
Table 2. Free radical scavenging activity of water extract from tomato powder

\begin{tabular}{lc}
\hline $\begin{array}{c}\text { Concentration } \\
(\mu \mathrm{g} / \mathrm{mL})\end{array}$ & Percentage inhibition $^{1}$ \\
\cline { 2 - 2 } & DPPH radical \\
10 & $13.84 \pm 0.45^{\mathrm{e}}$ \\
20 & $23.00 \pm 0.69^{\mathrm{d}}$ \\
25 & $60.98 \pm 2.15^{\mathrm{c}}$ \\
50 & $76.15 \pm 1.45^{\mathrm{a}}$ \\
100 & $75.26 \pm 3.15^{\mathrm{a}}$ \\
$\mathrm{EC}_{50}(\mu \mathrm{g} / \mathrm{mL})$ & $70.74 \pm 4.45^{\mathrm{b}}$ \\
\hline
\end{tabular}

${ }^{1}$ Values are represented as mean $\pm \mathrm{SD}(\mathrm{n}=4)$.

${ }^{2}$ Compared to ascorbic acid $\left(\mathrm{EC}_{50}=12.32 \pm 0.23 \mu \mathrm{g} / \mathrm{mL}\right)$.

${ }^{a-e}$ Means \pm standard deviation with different superscripts within the different concentration significantly differ at $\mathrm{p}<0.05$.

pork patties with over $0.5 \%$ tomato powder showed lower $(\mathrm{p}<0.05) \mathrm{pH}$ values than the control sample during storage. Similar results have been reported by Yilmaz et al. (2002) for Turkish sausages produced with tomato juice. The decrease of $\mathrm{pH}$ values of in meat products contained tomato paste have also been reported (Candogan, 2002; Deda et al., 2007). This can be attributed to the low $\mathrm{pH}$ value of TP (pH 3.48). But, during the one week storage time, the decreased $\mathrm{pH}$ values did not changed $(\mathrm{p}>0.05)$ in $\mathrm{T} 2, \mathrm{~T} 3$ and $\mathrm{T} 4$ of $\mathrm{TP}$ treated-patties.
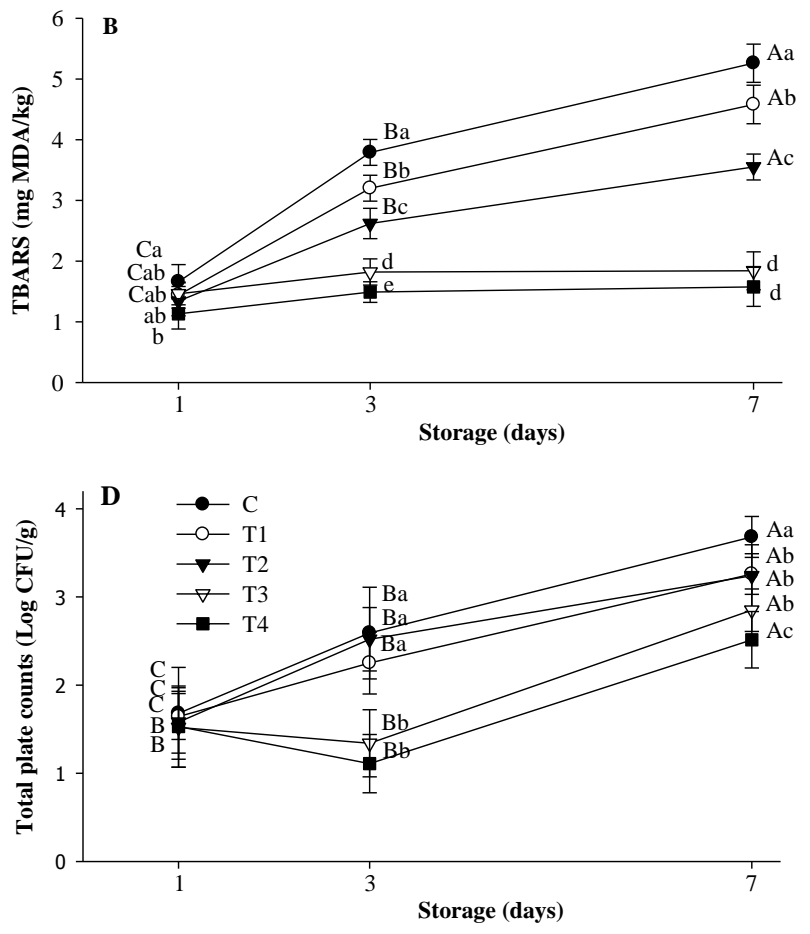

Figure 1. Change of $\mathrm{pH}(\mathrm{A})$, thiobarbituric acid reactive substances (TBARS, B), volatile basic nitrogen (VBN, C) and total plate counts (D) values of cooked pork patties with added tomato powder (TP) during storage at $10 \pm 1{ }^{\circ} \mathrm{C}$. Samples are added one of four levels of TP, $0.25 \%(\mathrm{~T} 1), 0.5 \%(\mathrm{~T} 2), 0.75 \%$ (T3) or $1.0 \%$ (T4) in basal formula (C). ${ }^{\mathrm{a}-\mathrm{d}}$ Means with different superscripts within the bars at the same concentration significantly differ at $\mathrm{p}<0.05 .{ }^{\mathrm{A}-\mathrm{C}}$ Means with different superscripts in the same treatment significantly differ at $\mathrm{p}<0.05$. 


\section{TBARS and VBN values of pork patties}

Figure 1 shows the results for TBARS (B) values of meat patties mixed with TP during storage at $10 \pm 1^{\circ} \mathrm{C}$. The TBARS values of $\mathrm{T} 3$ and $\mathrm{T} 4$ patties were not changed during storage $(p>0.05)$, but the TBARS values of $C, T 1$ and T2 patties increased $(\mathrm{p}<0.05)$ at the same storage period. At d 3 and 7 of storage, the TBARS values of TP-treated samples were significantly lower $(\mathrm{p}<0.05)$ than those of control. After 7 days of storage, the higher the concentration of TP in pork patties, the lower the TBARS values in all tested samples. This result is in agreement with a previous report (Condogan, 2002), who found that beef patties produced without sodium nitrite, but treated with 5\%, $10 \%$ and $15 \%$ tomato paste expressed lower $(p<0.05)$ TBARS values than the control, due to the antioxidative activity of tomato paste.

Figure 1C illustrates that VBN values of the meat patties significantly $(\mathrm{p}<0.05)$ increased as expected when storage time increased. This result agreed with other studies (Han et al., 2006; Kim et al., 2009). Increased value of volatile basic nitrogen (VBN), a result of protein breakdown of during storage by microorganisms, can be an index of loss of meat product freshness (Jay, 1992). Addition of TP did not significantly affect the VBN content in the meat patties until d 3 of storage. However, the VBN content in the meat patties with TP added above $0.5 \%$ was lower than that of control at storage on d 7 (5.94 vs 5.21 $\mathrm{mg} \%)$. This result represents a similar trend to the growth of total aerobic bacteria in the meat patties. The VBN content has been considered as spoilage indicator, and is increased by proteolysis carried out by microorganisms and enzymes in meat and meat products (Field and Chang, 1969; Jo et al., 2004). These results suggest that the shelflife of the pork patties may be improved slightly by $0.5 \%$ TP extract. However, all the samples for each group in this study did not exceed $20 \mathrm{mg} / 100 \mathrm{~g}$, which is the value that described as the level necessary to detect meat spoilage ( $\mathrm{Su}$ and Lin, 1988).

\section{Microbial counts of pork patties}

Figure 1D shows the results for the changes of total plate counts (TPC) values of pork patties treated with TP during storage at $10 \pm 1{ }^{\circ} \mathrm{C}$. No significant difference ( $p>$ 0.05 ) was observed in TPC of all patties at d 1 of storage. After 3 days of storage, the TPC values of C, T1, and T2 patties were significantly $(\mathrm{p}<0.05)$ increased compared with initial counts of TPC, however, those of T3 and T4 patties were not different from the initial counts of TPC. After 7 days of storage, the TPC values of all TP-treated samples showed significantly lower values $(\mathrm{p}<0.05)$ than the control patties. TPC value of the control samples increased steadily during storage and reached $3.68 \mathrm{log} \mathrm{CFU} / \mathrm{g}$ after $7 \mathrm{~d}$. But the TPC values of TP-treated patties were decreased by 0.42 , $0.44,0.83$ and $1.17 \log$ units in T1, T2, T3 and T4 patties, respectively, when compared to the control patties $(\mathrm{p}<0.05)$ after $7 \mathrm{~d}$. These results were in line with results found by some researchers who studied the antimicrobial effects of tomato (Yilmaz et al. 2002; Østerlie and Lerfall, 2005; Calvo et al., 2008). The low bacterial counts of TP-treated patties seemed to be results of antimicrobial contents such as phenolics in TP. Similarly, Shoko et al. (1999) reported that phenolics from medicinal plant were the most important compounds active against bacteria. Our results suggest that the use of tomato powder may be exploitable as an antibacterial agent to prevent the deterioration of stored meat products by bacteria. Counts of E. coli were not detected in all samples throughout the storage period (data are not shown) suggesting good hygienic quality in processing although the cooking procedures are probably the main reason.

\section{Instrumental colour of pork patties}

Figure 2 shows the results of the instrumental colour values of pork patties treated with TP during storage at $10 \pm 1^{\circ} \mathrm{C}$. The changes observed in parameters of colour were mainly related to the additional concentration of TP. Pork patties mixed with TP showed lower values $(\mathrm{p}<0.05)$ for lightness $\left(L^{*}\right)$, but higher values $(\mathrm{p}<0.05)$ for redness $\left(a^{*}\right)$ and yellowness $\left(b^{*}\right)$ than the patties without TP during storage. The lightness of control, T3 and T4 were not changed despite a week of storage, however, those of $\mathrm{T} 1$, T2 were decreased $(\mathrm{p}<0.05)$ after $7 \mathrm{~d}$. Redness of the control was decreased after $7 \mathrm{~d}$ in the refrigerator, but that of T4 decreased, while T1, T2 and T3 patties showed no change in redness even after 7 days of storage. This increased redness resulting from the added TP could be more attractive to consumers than the control sample. Application of lycopene pigment from tomato paste could improve the appearance of meat products (Condogan, 2002). Furthermore, minced meat mixed with a lycopenecontaining product could reduce or replace the use of nitrite (Østerlie and Lerfall, 2005).

\section{Sensory evaluation of pork patties}

Table 3 shows the results for sensory evaluation of TPtreated pork patties during storage at $10 \pm 1^{\circ} \mathrm{C}$. Pork patties of T3 and T4 samples scored higher $(\mathrm{p}>0.05)$ scores in colour than the control during storage. The high colour scores in the sensory evaluation might be a result of high redness and yellowness of TP. T3 and T4 patties. Also, these patties scored significantly higher values of flavour than those of the control at $\mathrm{d} 1$ and 7 of storage. This suggests that the addition of TP is an effective antioxidant in cooked meat patties and could also act against the attributes of 

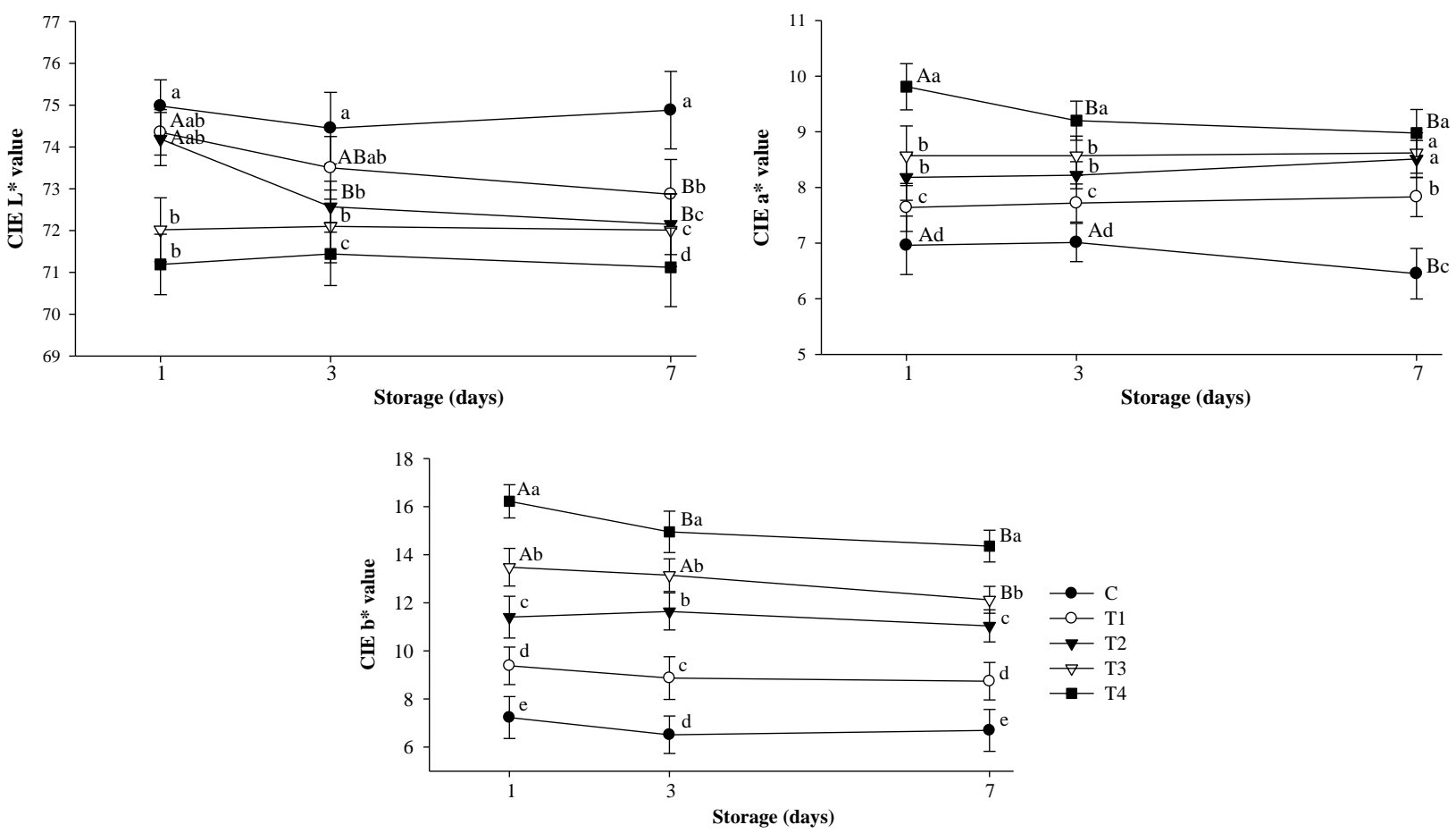

Figure 2. Change of meat color of cooked pork meat patties with added tomato powder during storage at $10 \pm 1^{\circ} \mathrm{C}$. Treatments are the same as described in Figure 1. ${ }^{\mathrm{a}-\mathrm{e}}$ Means with different superscripts in the same storage significantly differ at $\mathrm{p}<0.05$. ${ }^{\mathrm{A}, \mathrm{B}}$ Means with different superscripts in the same treatment significantly differ at $\mathrm{p}<0.05$.

warmed over flavor (WOF) in pork patties. The present results disagree with those of Hoe et al. (2006) who found that the $0.5 \%$ tomato powder did not change the sensory characteristics of emulsion sausages. After 3 and 7 days of storage, the scores of $\mathrm{T} 3$ and $\mathrm{T} 4$ patties had an overall acceptability that was higher than those of other patties, though, statistical significance was not found $(\mathrm{p}>0.05)$ at d 1 of storage. But increasing storage time decreased the sensory scores of colour, flavour and overall acceptance in all samples except for T3 and T4 TP-treated pork patties.

Table 3. Changes in sensory scores ${ }^{1}$ of cooked pork meat patties with added tomato powder during storage at $10 \pm 1^{\circ} \mathrm{C}$

\begin{tabular}{|c|c|c|c|c|}
\hline \multirow{2}{*}{ Treatments $^{2}$} & & \multicolumn{3}{|c|}{ Storage $(\mathrm{d})$} \\
\hline & & 1 & 3 & 7 \\
\hline \multirow[t]{5}{*}{ Color } & $\mathrm{C}$ & $6.13 \pm 0.54^{\mathrm{Ab}}$ & $5.70 \pm 0.58^{\mathrm{Ab}}$ & $5.24 \pm 0.66^{\mathrm{Bb}}$ \\
\hline & $\mathrm{T} 1$ & $6.33 \pm 0.52^{\mathrm{Ab}}$ & $6.25 \pm 0.64^{\mathrm{Ab}}$ & $5.17 \pm 0.58^{\mathrm{Bb}}$ \\
\hline & $\mathrm{T} 2$ & $6.83 \pm 0.63^{\mathrm{Ab}}$ & $6.25 \pm 0.85^{\mathrm{Bb}}$ & $5.43 \pm 0.74^{\mathrm{Cb}}$ \\
\hline & $\mathrm{T} 3$ & $7.17 \pm 0.47^{\mathrm{a}}$ & $6.75 \pm 0.61^{\mathrm{a}}$ & $6.67 \pm 0.89^{\mathrm{a}}$ \\
\hline & $\mathrm{T} 4$ & $7.17 \pm 0.44^{\mathrm{a}}$ & $6.98 \pm 0.91^{\mathrm{a}}$ & $6.50 \pm 0.79^{\mathrm{a}}$ \\
\hline \multirow[t]{5}{*}{ Flavor } & $\mathrm{C}$ & $6.33 \pm 0.45^{\mathrm{Ab}}$ & $5.90 \pm 0.52^{\mathrm{A}}$ & $4.67 \pm 0.32^{\mathrm{Bb}}$ \\
\hline & $\mathrm{T} 1$ & $6.23 \pm 0.52^{\mathrm{Ab}}$ & $6.10 \pm 0.49^{\mathrm{A}}$ & $4.75 \pm 0.46^{\mathrm{Bb}}$ \\
\hline & $\mathrm{T} 2$ & $6.50 \pm 0.63^{\mathrm{Ab}}$ & $6.40 \pm 0.53^{\mathrm{A}}$ & $4.92 \pm 0.56^{\mathrm{Bb}}$ \\
\hline & $\mathrm{T} 3$ & $7.17 \pm 0.35^{\mathrm{a}}$ & $6.50 \pm 0.57$ & $6.17 \pm 0.52^{\mathrm{a}}$ \\
\hline & $\mathrm{T} 4$ & $7.13 \pm 0.41^{\mathrm{a}}$ & $6.40 \pm 0.50$ & $6.21 \pm 0.61^{\mathrm{a}}$ \\
\hline \multirow[t]{5}{*}{ Overall acceptability } & $\mathrm{C}$ & $6.85 \pm 0.75^{\mathrm{A}}$ & $6.20 \pm 0.56^{\mathrm{Ab}}$ & $4.16 \pm 0.69^{\mathrm{Bb}}$ \\
\hline & $\mathrm{T} 1$ & $6.83 \pm 0.65^{\mathrm{A}}$ & $6.25 \pm 0.65^{\mathrm{Ab}}$ & $4.87 \pm 0.59^{\mathrm{Bb}}$ \\
\hline & $\mathrm{T} 2$ & $6.83 \pm 0.62^{\mathrm{A}}$ & $6.25 \pm 0.85^{\mathrm{Ab}}$ & $5.48 \pm 0.72^{\mathrm{Bab}}$ \\
\hline & $\mathrm{T} 3$ & $7.17 \pm 0.58$ & $6.94 \pm 0.79^{\mathrm{a}}$ & $6.42 \pm 0.74^{\mathrm{a}}$ \\
\hline & $\mathrm{T} 4$ & $7.00 \pm 0.62$ & $7.13 \pm 0.62^{\mathrm{a}}$ & $6.53 \pm 0.77^{\mathrm{a}}$ \\
\hline
\end{tabular}

\footnotetext{
${ }^{1}$ Sensory scores were assessed on 9 point scale where $1=$ extremely undesirable, $9=$ extremely desirable.

${ }^{2}$ Treatments are the same as described in Figure 2.

${ }^{\mathrm{a}-\mathrm{c}}$ Means with different superscripts in the same column significantly differ at $\mathrm{p}<0.05$.

${ }^{\mathrm{A}-\mathrm{C}}$ Means with different superscripts in the same row significantly differ at $\mathrm{p}<0.05$.
} 


\section{CONCLUSION}

Tomato powder (TP)-treated pork patties enriched in total flavonoid contents showed good sensory quality in colour, aroma and overall acceptability after storage, which could be caused by significantly higher redness and yellowness and inhibited lipid oxidation. Modern consumers are increasingly concerned about the safety of meat products and undesirable effects of meat on their health. Therefore, the results of this report suggests that TP, as a natural additive, can be used to extend the shelf-life of pork and possibly other meat products providing the consumer with food that contains only natural additives, which would be seen as healthier than those with synthetic additives.

\section{ACKNOWLEDGEMENT}

This research was supported by the Priority Research Centers Program through the National Research Foundation of Korea (NRF) funded by the Ministry of Education, Science and Technology (2012-0006683) and Export Promotion Technology Development Program funded by Ministry for Food, Agriculture, Forestry and Fisheries, Republic of Korea.

\section{REFERENCES}

Bondet, V., W. Brand-Williams, and C. Berset. 1997. Kinetics and mechanisms of antioxidant activity using the DPPH free radical method. LWT-Food Sci. Technol. 30:609-615.

Brand-Williams, W., M. E. Cuvelier, and C. Berset. 1995. Use of a free radical method to evaluate antioxidant activity. LWT-Food Sci. Technol. 28:25-30.

Barba, A. I. O., M. C. Hurtado, M. C. S. Mata., V. F. Ruiz, and M. L. S. Tejada. 2006. Application of a UV-vis detection-HPLC method for a rapid determination of lycopene and b-carotene in vegetables. Food Chem. 95:328-336.

Calvo, M. M., M. L. Garciia, and D. M. Selgas. 2008. Dry fermented sausages enriched with lycopene from tomato peel. Meat Sci. 80:167-172.

Candogan, K. 2002. The effect of tomato paste on some quality characteristics of beef patties during refrigerated storage. Eur. Food Res. Technol. 215:305-309

CIE (Commission International de l'Eclairage). 1976. Official recommendations on uniform color spaces. Color difference equations and metric color terms, Suppl. No. 2. CIE Publication No. 15 Colorimetry. Paris.

Deda, M. S., J. G. Bloukas, and G. A. Fista. 2007. Effect of tomato paste and nitrite level on processing and quality characteristics of frankfurters. Meat Sci. 76:501-508.

Field, R. A. and Y. D. Chang. 1969. Free amino acids in bovine muscle and their relationship to tenderness. J. Food Sci. 34:329-331.

Garcia-Closas, R., C. Gonzales, A. Aguda, and E. Riboli. 1999. Intake of specific carotenoids and flavonoids and the risk of gastric cancer in Spain. Cancer Causes Control 10:71-75.

Gartner, C., W. Stah, and H. Sies. 1997. Lycopene is more bioavailable from tomato paste than from fresh tomatoes. Am. J. Clin. Nutr. 66:116-122.

Grieb, S. M. D., R. P. Theis, D. Burr, D. Benardot, T. Siddiqui, and N. R. Asal. 2009. Food groups and renal cell carcinoma: results from a case-control study. J. Am. Diet. Assoc. 109:656667.

Gyamfi, M. A., M. Yonamine, and Y. Aniya. 1999. Free-radical scavenging action of medicinal herbs from Ghana: Thonningia sanguine on experimentally-induced liver injuries. Gen. Pharmacol. 32:661-667.

Han, K. H., I. S. Choi, and C. H. Lee. 2006. The physicochemical and storage characteristics of sausage added mugwort powder. Korean J. Food Sci. An. 26:356-361.

Havsteen, B. 1983. Flavonoids, a class of natural-products of high pharmacological potency. Biochem. Pharmacol. 32:1141-1148.

Hemi, K. E., A. R. Taigliaferro, and D. J. Bobilya. 2002. Flavonoids antioxidant chemistry, metabolism and structure activity relationship. J. Nutr. Biochem. 13:572-584.

Henry, L. K., G. L. Catignani, and S. J. Schwartz. 1998. Oxidative degradation kinetics of lycopene, lutein, and 9-cis and all-trans $\beta$-carotene. J. Am. Oil Chem. Soc. 75:823-829.

Hertog, M. G. L., E. J. M. Feskens, P. C. H. Hollman, M. B. Katan, and D. Kromhout. 1993. Dietary antioxidant flavonoids and risk of coronary heart disease: the Zutphen Eldery study. Lancet 342:1007-1011.

Hoe, S. K., K. H. Park, M. R. Yang, K. J. Jeong, D. H. Kim, S. K. Choi, and I. S. Kim. 2006. Quality characteristics of low-fat emulsified sausage containing tomatoes during cold storage. Korean J. Food Sci. An. 26:297-305.

Hollman, P. C. H., M. G. Hertog, and M. B. Katan. 1996. Analysis and health effects of flavonoids. Food Chem. 57:43-46.

Hornero-Méndez, D. and M. I. Mínguez-Mosquera. 2007 Bioaccessibility of carotenes from carrots: effect of cooking and addition of oil. Innov. Food Sci. Emerg. Technol. 8:407412.

Hudson, B. J. F. and J. I. Lewis. 1983. Polyhydroxy flavonoid antioxidant for edible oils-structural criteria for activity. Food Chem. 10:47-55.

Jay, J. M. 1992. Modern food microbiology. In: Chapman and Hall 4th ed., New York. pp. 820-821.

Jo, C., D. H. Kim, H. Y. Kim, W. D. Lee, H. K. Lee, and M. W. Byun. 2004. Studies on the development of low-salted, fermented, and seasoned Changran Jeotkal using the intestines of Therage chalcogramma. Radiat. Phys. Chem. 71:123-126.

Khachik, F., L. Carvalho, P. S. Bernstein, G. J. Muir, D. Y. Zhao, and N. B. Katz. 2002. Chemistry, distribution, and metabolism of tomato carotenoids and their impact on human health. Exp. Biol. Med. 227:845-851.

Kim, I. S., S. K. Jin, S. N. Kang, I. C. Hur, and S. Y. Choi. 2009. Effect of olive-oil prepared tomato powder (OPTP) and refining lycopene on the physicochemical and sensory characteristics of seasoned raw pork during storage. Korean J. Food Sci. An. 29(3):334-339.

Knekt, P., R. Jarvinen, R. Seppanen, M. Heliovaara, L. Teppo, E. Pukkala, and A. Aromaa. 1997. Dietary flavonoids and the risk of lung cancer and other malignant neoplasms. Am. J. Epidemiol. 146:223-230. 
Meda, A., C. E. Lamien, M. Romito, J. Millogo, and O. G. Nacoulma. 2005. Determination of the total phenolic, flavonoid and proline contents in Burkina Fasan honey, as well as their radical scavenging activity. Food Chem. 91:571-577.

Østerlie, M. and J. Lerfall. 2005. Lycopene from tomato products added minced meat. Effect on storage quality and colour. Food Res. Int. 38:925-929.

Padayatty, S., A. Katz, Y. Wang, P. Eck, O. Kwon, and J. Lee. 2003. Vitamin $\mathrm{C}$ as an antioxidant: Evaluation of its role in disease prevention. J. Am. College Nutr. 22:18-35.

Pearson, D. 1968. Application of chemical methods for the assessments of beef quality. J. Sci. Food Agric. 19:366-369

Sánchez-Escalante, A., G. Torrescano, D. Djenane, J. A. Beltran, and P. Roncales. 2003. Stabilization of colour and odour of beef patties using lycopene-rich tomato and peppers as a source of antioxidants. J. Sci. Food Agric. 83:187-194.

Sánchez-Moreno, C., J. A. Larrauri, and F. A. Saura-Calixto. 1998. A procedure to measure the antiradical efficiency of polyphenols. J. Sci. Food Agric. 76:270-276.

SAS. 1999. SAS/STAT Software for PC. Release 6.11, SAS Institute, Cary, NC, USA.

Sies, H. and W. Stahl. 1998. Lycopeneantioxidant and biological effects and its bioavailability in the human. Proc. Soc. Exp. Biol. Med. 218:121-124.

Singleton, V. L. and J. R. Rossi. 1965. Colorimetry of total phenolics with phosphomolybdic-phosphotungstic acid reagents. Am. J. Enol. Vitic. 16:144-158.
Stahl, W. and H. Sies. 1992. Uptake of lycopene and its geometrical isomers is greater from heat-processed than from unprocessed tomato juice in humans. J. Nutr. 1122:2161-2166.

$\mathrm{Su}$, H. P. and C. W. Lin. 1988. A survey of the storage characteristics of dried sliced pork. J. Chin. Soc. Anim. Sci. 17:83-90.

Tapiero, H., M. D. Townsend, and W. D. Tew. 2004. The role of carotenoids in the prevention of human pathologies. Biomed. Pharmacother. 58:100-110.

Tarladgis, B. G., B. M. Watts, M. T. Younathan, and L. Dugan. 1960. A distillation method for the quantitative determination of malonaldehyde in racid foods. J. Am. Oil Chem. Soc. 37:4448.

Toor, R. K. and G. P. Savage. 2005. Antioxidant activity in different fractions of tomatoes. Food Res. Int. 38:487-494.

Vinson, J. A., Y. Hao, X. Su, L. Zubik, Y. Hao, and X. H. Su. 1998. Phenol antioxidant quantity and quality in foods: vegetables. J. Agri. Food Chem. 46:3630-3634.

Yilmaz, I., O. Simsek, and M. Isikli. 2002. Fatty acid composition and quality characteristics of low-fat cooked sausage made with beef and chicken meat, tomato juice and sunflower oil. Meat Sci. 62:253-258.

Zhang, C. X., S. C. Ho, Y. M. Chen, J. H. Fu, S. Z. Cheng, and F. Y. Lin. 2009. Greater vegetable and fruit intake is associated with a lower risk of breast cancer among Chinese women. Int. J. Cancer 125:181-188. 